\title{
Occurrence of 16:2(n-4) and 18:2(n-4) fatty acids in the lipids of the hydrothermal vent shrimps Rimicaris exoculata and Alvinocaris markensis: nutritional and trophic implications
}

\author{
David W. Pond ${ }^{1,2, *}$, David R. Dixon ${ }^{2}$, Michael V. Bell ${ }^{1}$, Anthony E. Fallick ${ }^{3}$, \\ John R. Sargent ${ }^{1}$
}

'NERC Unit of Aquatic Biochemistry, Department of Biological and Molecular Sciences, University of Stirling, Stirling FK9 4LA, United Kingdom

${ }^{2}$ Plymouth Marine Laboratory, Prospect Place, Plymouth PL1 3DH, United Kingdom

${ }^{3}$ Isotope Geosciences Unit, SURRC, East Kilbride, Glasgow G75 OQF, United Kingdom

\begin{abstract}
Adults of 2 species of vent shrimp, Rimicaris exoculata and Alvinocaris markensis, were sampled from the Snake Pit and TAG hydrothermal vent sites on the mid-Atlantic ridge. Fatty acid analyses indicated high abundances of $16: 2(n-4)$ and $18: 2(n-4)$ in the lipids of $R$. exoculata, with the highest proportions of these fatty acids detected in the digestive gland $[14.5 \% 16: 2(n-4)$ and $23.8 \%$ 18:2(n-4)]. Lipid extracted from abdominal muscle of $R$. exoculata also contained these fatty acids, although in lower proportions $[2.0 \% 16: 2(n-4)$ and $14.5 \% 18: 2(n-4)]$. By contrast, lipid extracted from the same tissues in $A$. markensis contained relatively low proportions of (n-4) fatty acids ( 1.9 to $3.0 \%$ ), but was substantially enriched in the phototrophic, microplanktonic biomarkers 20:5(n-3) and 22:6(n3). GC-IRMS (gas chromatography with isotope ratio mass spectrometry) analysis of the (n-4) dienoic fatty acids established $\delta^{13} \mathrm{C}$ values of -11.0 to $-11.4 \%$ which is consistent with the fatty acids being derived from chemosynthetically fixed carbon. By contrast, those fatty acids which are characteristic of phototrophic microplankton were isotopically lighter, i.e. $-17.1,-17.3$ and $-15.8 \%$ for $20: 4(n-6), 20: 5$ (n3 ) and 22:6(n-3) respectively. The non-methylene interrupted dienes (NMIDs) 20:2 $\Delta 5,13$ and 22:2 $\Delta 7,15$ were detected in all samples although in small amounts with $R$. exoculata containing the highest amounts. The (n-4) dienes and NMIDs are consistent with a substantial dietary input of bacterially derived 16:1(n-7) and 18:1(n-7) fatty acids for this species. Thus, these results are consistent with $R$. exoculata adopting a bacterivorous mode of nutrition whilst $A$. markensis is essentially a scavenger (necrophagous) and suggest that the 2 species are not in direct competition for their food supply.
\end{abstract}

KEY WORDS: Hydrothermal vent shrimp - Fatty acids - Nutrition - Trophic ecology Stable carbon isotope $\cdot \triangle 12$ desaturase $(n-4)$ PUFA

\section{INTRODUCTION}

The deep-sea ecosystem localised around the hydrothermal vent sites on the mid-Atlantic ridge (MAR) is considered to be predominantly based on carbon fixed by chemoautolithotrophic bacteria (Van Dover 1995). However, although numerous studies have indicated that the bulk of productivity at the vent sites is of bacterial origin, the quantitative significance and contri-

-E-mail: dwp1@stirling ac.uk bution of photosynthetically derived material for the nutrition of these communities has not been established (Rieley et al. 1995).

Caridean shrimp belonging to the family Alvinocarididae are the dominant megafauna at MAR vent sites (Segonzac 1992, Van Dover 1995) and Rimicaris exoculata is particularly abundant, forming characteristic, dense feeding swarms around hydrothermal chimneys and vents (Rona 1986, Gebruk et al. 1993). A further species, Alvinocaris markensis, is generally less abundant and tends to be located away from the vent source 
(Segonzac et al. 1993). R. exoculata supports a rich bacterial epibiosis on its gills and within its gill chambers (Casanova et al. 1993) and its mouthparts are hypertrophied and densely covered with setae, which substantially increases the surface area for attachment and growth of bacteria (Gebruk et al. 1993), or is an adaptation for bacterial feeding (Segonzac 1992). Van Dover et al. (1988) suggested that the primary source of nutrition for $R$. exoculata was bacteria living on the surface of chimney sulphides, but that epibiotic bacteria may also contribute to its diet. More recently Gebruk et al. (1993) argued that the levels of epibiotic bacteria on $R$. exoculata are sufficient to meet its entire dietary requirements and that the shrimps maintain close proximity to hydrothermal fluid to 'farm' their bacterial symbionts.

In contrast, Alvinocaris markensis does not appear to support epibiotic bacteria, nor does it actively swim on the periphery of the vent plumes (Casanova et al. 1993). Observations of the morphology and in situ behaviour of these 2 species led Segonzac et al. (1993) to speculate that they occupy different ecological niches, i.e. Rimicaris exoculata was considered to be a primary consumer, whilst $A$. markensis was considered exclusively necrophagous.

Fatty acid biomarker compounds have previously been utilised to provide useful insights into the trophic interactions between marine consumers and their food supply (Sargent et al. 1987, Fullarton et al. 1995, Pranal et al. 1996, St. John \& Lund 1996). More recently, conventional gas chromatography has been coupled with isotope ratio mass spectrometry (GC-IRMS) to determine the ${ }^{13} \mathrm{C} /{ }^{12} \mathrm{C}$ isotopic composition of individual fatty acids (Fang et al. 1993a, Abrajano et al. 1994). The isotopic signature of compounds within an organism results from the combined effects of dietary sources and metabolic isotopic fractionations and can therefore provide useful insights into marine food webs (Hayes 1993).

In this study we analysed the fatty acid compositions of the vent shrimp Rimicaris exoculata and Alvinocaris markensis to improve our understanding of their sources of nutrition and trophic ecology.

\section{METHODS}

Station locations and description. Adult Rimicaris exoculata were obtained from collections made during the NERC-BRIDGE funded Anglo-Russian cruise (BRAVEX) to the TAG vent site $\left(26^{\circ} \mathrm{N}, \mathrm{MAR}\right)$, in the summer of 1994, whilst Alvinocaris markensis and a further specimen of $R$. exoculata were obtained from a collection made from the adjacent Snake Pit site $\left(23^{\circ} \mathrm{N}\right)$ during the French HYDROSNAKE cruise in 1988. All specimens were deep frozen $\left(-70^{\circ} \mathrm{C}\right)$ shortly after collection and, after dissection, the tissues were transported to the laboratory either in BLB buffer $15 \%$ sodium dodecylsulphate, $250 \mathrm{mM}$ EDTA, $50 \mathrm{mM}$ Tris$\mathrm{HCl}, \mathrm{pH}$ 8) or chloroform:methanol 2:1. Parallel DNA studies showed the tissue samples to be in an excellent state of preservation, based on the recovery of highmolecular-weight genomic DNA with virtually no evidence of enzymatic degradation (Dixon et al. unpubl.).

Fatty acid analysis. Tissue samples were homogenised in chloroform:methanol 2:1 (v/v) before filtering through a prewashed (chloroform:methanol 2:1 $\mathrm{v} / \mathrm{v}$ ) Whatman No. 1 paper filter. Total lipid was then extracted following Folch et al. (1957) and dried under nitrogen before transmethylation in absolute methanol containing $1.5 \%(\mathrm{v} / \mathrm{v})$ sulphuric acid for $16 \mathrm{~h}$ at $50^{\circ} \mathrm{C}$ (Christie 1982). After extraction and purification, component fatty acids were identified by chromatography on a Canberra $436 \mathrm{GC}$ fitted with a BP20 fused silica capillary column (50 $\mathrm{m} \times 0.32 \mathrm{~mm}$ i.d., SGE) using hydrogen as carrier gas (Henderson et al. 1994). Peaks were identified by reference to samples of known composition and by GC-MS using a Fisons MD 800 fitted with a DB-5MS column $(15 \mathrm{~m} \times 0.25 \mathrm{~mm}$ i.d., $\mathrm{J} \& \mathrm{~W}$ Scientific) using helium as carrier gas. The running order of fatty acids is as shown in Table 1.

Diene characterisation. To reduce co-elution and improve GC-MS, the total fatty acid methyl esters were separated into saturated, monounsaturated and polyunsaturated fatty acid fractions by argentation high-performance thin-layer chromatography (HPTLC) using hexane:diethyl ether $(90: 10 \mathrm{v} / \mathrm{v}$ ) (Wilson \& Sargent 1992). Fatty acid diethylamides were then prepared by the method of Nilsson \& Liljenberg (1991) and identified by GC-MS operated in EI negative mode. Diethylamide derivatives of the (n-4) dienes and nonmethylene interrupted dienes (NMIDs) were characterised by GC-MS as follows: $16: 2(\mathrm{n}-4) \mathrm{m} / \mathrm{z}\left[\mathrm{M}^{+}\right] 307$ and $26 \mathrm{~m} / \mathrm{z}$ gaps at m/z 264 to 238 and 224 to 198 indicated $\Delta 12$ and $\Delta 9$ double bonds; $18: 2(\mathrm{n}-4) \mathrm{m} / \mathrm{z}\left[\mathrm{M}^{+}\right]$ 335 , and $26 \mathrm{~m} / \mathrm{z}$ gaps at $\mathrm{m} / \mathrm{z} 292$ to 260 and 252 to 226 indicated $\Delta 14$ and $\Delta 11$ double bonds; $20: 2(\mathrm{n}-4) \mathrm{m} / \mathrm{z}$ $\left[\mathrm{M}^{2}\right] 363$, and $26 \mathrm{~m} / \mathrm{z}$ gaps at $\mathrm{m} / \mathrm{z} 320$ to 294 and 280 to 254 indicated $\Delta 16$ and $\Delta 13$ double bonds; $20: 2 \Delta 5,13 \mathrm{~m} / \mathrm{z}\left[\mathrm{M}^{+}\right] 363$ and $26 \mathrm{~m} / \mathrm{z}$ gaps at $\mathrm{m} / \mathrm{z} 278$ to 252 and 168 to 142 indicated $\Delta 13$ and $\Delta 5$ double bonds: $22: 2 \Delta 7,15 \mathrm{~m} / \mathrm{z}\left[\mathrm{M}^{+}\right] 391$, and $26 \mathrm{~m} / \mathrm{z}$ gaps at $\mathrm{m} / \mathrm{z} 306$ to 280 and 196 to 170 indicated $\Delta 7$ and $\Delta 15$ double bonds.

${ }^{13} \mathrm{C} /{ }^{12} \mathrm{C}$ analyses. Carbon stable isotope ratios $\left({ }^{13} \mathrm{C} /{ }^{12} \mathrm{C}\right)$ were measured by GC-IRMS using a VG Isochrom II instrument whose performance has been described by Eakin et al. (1992). A fused silica capillary column (SGE: BP20, $50 \mathrm{~m} \times 0.32 \mathrm{~mm}$, i.d. $0.5 \mu \mathrm{m}$ ) was used with helium as the carrier gas and a splitless injection mode was employed. The temperature pro- 
gram was: $50^{\circ} \mathrm{C}(0.1 \mathrm{~min})$ rising to $190^{\circ} \mathrm{C}$ with a $40^{\circ} \mathrm{C}$ $\mathrm{min}^{-1}$ gradient, then rising to $230^{\circ} \mathrm{C}(50 \mathrm{~min})$ with a $2.5^{\circ} \mathrm{C} \mathrm{min}^{-1}$ gradient. The dienoic fatty acids samples were injected in duplicate and compared with a reference $\mathrm{CO}_{2}$ source which was calibrated for $\delta^{13} \mathrm{C}(\%)$ by conventional dual-inlet mass spectrometry with reference to Peedee Belemnite (PDB). Replicate analyses suggest a precision of $\pm 0.4 \%$. The $\delta^{13} \mathrm{C}$ composition of the methanol derivatization reagent was determined as $-41.8 \%$ by the quartz closed tube combustion technique of Sofer (1980). The contribution of the derivatized carbon was calculated by rearranging the equation of Abrajano at al. (1994) and assumes that there is no isotopic fractionation during derivatization.

$$
\delta^{13} \mathrm{C}_{\text {FA }}=\frac{\delta^{13} \mathrm{C}_{\text {FAME }}-(1-x) \delta^{13} \mathrm{C}_{\mathrm{CH}_{3} \mathrm{OH}}}{x}
$$

where $\delta^{13} \mathrm{C}_{\mathrm{FA}}$ is the isotopic composition of the free fatty acid, $\delta^{13} \mathrm{C}_{\text {FAME }}$ is the isotopic composition of the fatty acid methyl ester, $x$ is the fractional carbon contribution of the free fatty acid to the ester and $\delta^{13} \mathrm{C}_{\mathrm{CH}_{3} \mathrm{OH}}$ is the isotopic composition of the methanol derivatization reagent.

\section{RESULTS}

Bulk fatty acid compositions of total lipid extracted from Rimicaris exoculata collected from the TAG site and Alvinocaris markensis from the Snake Pit site were essentially similar, comprising approximately 36 to $40 \%$ saturated fatty acids (SFA), 14 to $20 \%$ monounsaturated fatty acids (MUFA) and 40 to $50 \%$ polyunsaturated fatty acids (PUFA) (Table 1). The fatty acid composition of a single specimen of $R$. exoculata from the Snake Pit also fitted this pattern (Table 1). However, detailed fatty acid analyses indicated substantial differences between the 2 species

As the MUFA 18:1(n-7) is generally an abundant constituent of bacterial lipids, the ratio of $18: 1(n-9) /$ $18: 1(n-7)$ can give a useful indication of the contribu-

Table 1. Alvinocaris markensis, Rimicaris exoculata. Fatty acid composition of total lipid from various tissues of vent shrimp from the Snake Pit and TAG hydrothermal vent sites. (Only mean values are presented for clarity; $\mathrm{tr}=<0.1 \%$ )

\begin{tabular}{|c|c|c|c|c|c|c|c|}
\hline \multirow[t]{2}{*}{ Fatty acid } & \multicolumn{3}{|c|}{ Snake Pit } & \multicolumn{4}{|c|}{$\begin{array}{c}\text { TAG } \\
R . \text { exoculata }\end{array}$} \\
\hline & $\begin{array}{l}\text { Digestive gland } \\
\qquad(\mathrm{n}=3)\end{array}$ & $\begin{array}{c}\text { Tail } \\
(n=3)\end{array}$ & $\begin{array}{l}\text { Digestive gland } \\
\qquad(\mathrm{n}=1)\end{array}$ & $\begin{array}{l}\text { Digestive gland } \\
\qquad(\mathrm{n}=3)\end{array}$ & $\begin{array}{c}\text { Tail } \\
(\mathrm{n}=3)\end{array}$ & $\begin{array}{c}\text { Carapace } \\
(n=3)\end{array}$ & $\begin{array}{l}\text { Gills } \\
(\mathrm{n}=3)\end{array}$ \\
\hline $14: 0$ & 1.7 & 0.8 & 5.2 & 4.7 & 0.7 & 2.1 & 2.3 \\
\hline $14: 1$ & 1.2 & 2.0 & 1.4 & $\operatorname{tr}$ & $\operatorname{tr}$ & 2.0 & 3.3 \\
\hline $15: 0$ & 0.5 & 0.2 & 0.1 & 0.1 & 0.2 & 0.1 & 0.2 \\
\hline $16: 0$ & 13.3 & 9.4 & 6.4 & 7.2 & 9.7 & 7.2 & 9.4 \\
\hline $16: 1(n-7)$ & 9.0 & 5.5 & 22.3 & 19.7 & 11.1 & 19.0 & 19.4 \\
\hline $16: 2(n-3)$ & 0.8 & 0.4 & 0.8 & 0.6 & 1.6 & 0.2 & 0.2 \\
\hline $16: 2(n-4)$ & 0.4 & 1.6 & 10.7 & 14.5 & 2.0 & 7.0 & 9.4 \\
\hline $17: 0$ & 0.5 & 0.3 & 0.2 & 0.3 & 1.8 & 0.2 & 0.2 \\
\hline $16: 3(n-3)$ & 0.5 & 0.3 & 0.3 & 0.2 & 0.4 & 0.8 & 0.5 \\
\hline $16: 4(n-3)$ & $\operatorname{tr}$ & $\operatorname{tr}$ & $\operatorname{tr}$ & $\operatorname{tr}$ & $\operatorname{tr}$ & 1.9 & 1.2 \\
\hline 18:0 & 3.8 & 3.5 & 1.4 & 1.5 & 3.7 & 1.9 & 1.9 \\
\hline $18: 1(n-9)$ & 16.8 & 12.5 & 3.6 & 2.5 & 8.4 & 6.6 & 4.9 \\
\hline $18: 1(n-7)$ & 12.5 & 18.0 & 14.3 & 12.8 & 16.6 & 13.0 & 11.9 \\
\hline $18: 2(n-6)$ & 1.5 & 1.0 & $\operatorname{tr}$ & 0.1 & 0.5 & 0.4 & 0.5 \\
\hline $18: 2(n-4)$ & 1.5 & 1.4 & 19.9 & 23.8 & 13.0 & 15.9 & 17.5 \\
\hline $18: 3(n-3)$ & 0.6 & 0.5 & 0.1 & 0.1 & 0.3 & 1.3 & 1.2 \\
\hline $18: 4(n-3)$ & 1.1 & 1.0 & 0.1 & $\operatorname{tr}$ & 0.3 & 0.3 & $\operatorname{tr}$ \\
\hline $20: 0$ & 0.2 & 0.2 & 0.1 & 0.1 & 0.4 & 2.1 & 0.2 \\
\hline $20: 1(n-9)$ & 1.5 & 1.0 & 0.7 & 0.6 & 1.1 & 0.5 & 0.7 \\
\hline 20:2 NMID & 0.2 & 0.2 & 1.3 & 1.1 & 0.3 & 1.8 & 1.4 \\
\hline $20: 2(n-4)$ & $\operatorname{tr}$ & $\operatorname{tr}$ & $\operatorname{tr}$ & $\operatorname{tr}$ & $\operatorname{tr}$ & $\operatorname{tr}$ & $\operatorname{tr}$ \\
\hline $20: 4(n-6)$ & 2.5 & 3.6 & 0.9 & 1.0 & 2.6 & 2.7 & 1.9 \\
\hline $20: 4(n-3)$ & 0.6 & 0.7 & 0.1 & $\operatorname{tr}$ & 0.1 & $\operatorname{tr}$ & $\operatorname{tr}$ \\
\hline $20: 5(n-3)$ & 7.9 & 16.2 & 2.6 & 2.9 & 9.7 & 6.1 & 4.7 \\
\hline $22: 0$ & 0.2 & 0.4 & 0.4 & 0.2 & 0.8 & 0.2 & $\operatorname{tr}$ \\
\hline $22: 1(n-9)$ & 0.4 & 0.6 & 0.3 & 0.3 & 0.8 & 0.7 & 0.5 \\
\hline 22:2 NMID & 0.7 & 0.5 & 1.5 & 1.2 & 1.3 & 1.3 & 1.1 \\
\hline $22: 2(n-4)$ & $\operatorname{tr}$ & $\mathrm{tr}$ & $\mathrm{tr}$ & $\operatorname{tr}$ & $\operatorname{tr}$ & $\operatorname{tr}$ & $\operatorname{tr}$ \\
\hline $22: 5(n-3)$ & 1.4 & 0.6 & $\operatorname{tr}$ & $\operatorname{tr}$ & 0.5 & 0.2 & 0.3 \\
\hline $22: 6(n-3)$ & 18.1 & 17.1 & 4.8 & 3.9 & 11.4 & 3.9 & 4.5 \\
\hline $24: 1(n-9)$ & 0.6 & 0.5 & 0.5 & 0.4 & 0.7 & 0.5 & 0.7 \\
\hline
\end{tabular}



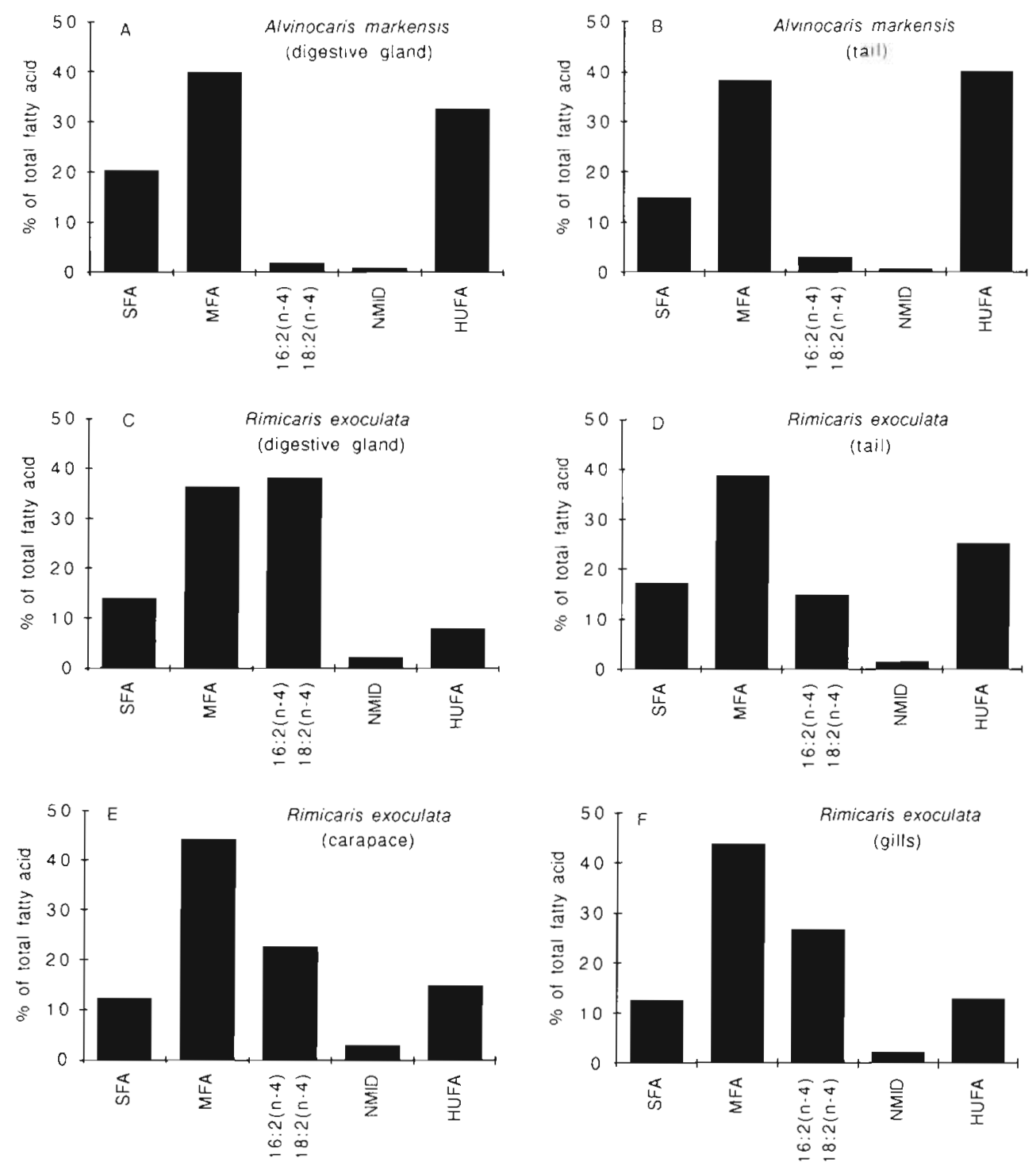

Fig. 1. Proportions of different groups of fatty acids from. various tissues in Alvinocans markensis and Rimicaris exoculata sampled from the Snake pil and TAG vent sites respectively. SFA = saturated fatty acid, MFA = monounsaturated fatty acid, NMID = nonmethylene interrupted diunsaturated fatty acid, HUFA = highly unsaturated fatty acids, i.e. 3 or more double bonds

tion of bacteria to the nutrition of marine organisms (Sargent et al. 1987). The lowest ratio for these fatty acids was in the digestive gland of Rimicaris exoculata (0.2) whilst abdominal muscle, carapace and gills gave values of ca 0.4 to 0.5 . However, the much larger amounts of $18: 1(\mathrm{n}-9)$ in Alvinocaris markensis gave a much higher ratio of $18: 1(n-9) / 18: 1(n-7)$, with values of 0.7 and 1.3 for abdominal muscle and digestive gland respectively. These results suggest a higher dietary input of bacteria for $R$. exoculata than A. markensis. The MUFA $16: 1(n-7)$, which is also abundant in bacteria, was also a major fatty acid in the shrimps and particularly the digestive gland, carapace and gills of $R$. exoculata where epibiotic bacteria were likely to con- tribute to the analyses. 16:1(n-7) was detected in lower amounts in A markensis and comprised only 9.0 and $5.5 \%$ of total fatty acid for digestive gland and abdominal respectively.

Rimicaris exoculata contained high levels of the diunsaturated fatty acids $16: 2(n-4)$ and $18: 2(n-4)$ (Fig. 1, Table 1). The digestive gland was particularly rich in these compounds where they comprised 14.5 and $23.8 \%$ of total fatty acids respectively. The fatty acid composition of the single specimen of $R$. exoculata from the Snake Pit site was very similar to those from the TAG site and also contained high levels of ( $n-4)$ fatty acids. Other tissues in $R$. exoculata contained substantial proportions of these fatty acids, i.e. in rank order of compositional abun- 
dance: gills > carapace > abdominal muscle (Table 1). Although (n-4) fatty acids were detected in Alvinocaris markensis, they comprised a much smaller proportion of the fatty acid pool and, when combined, only constituted 1.9 and $3.0 \%$ for digestive gland and abdominal muscle respectively. GC-IRMS analysis of these dienoic fatty acids from the gills of $R$. exoculata indicated that the $\delta^{13} \mathrm{C}$ compositions were similar, i.e. -11.0 and $-11.4 \%$ for 16:2(n-4) and 18:2(n-4) respectively (Table 2 ). By contrast, the fatty acids which are characteristic of phototrophic microplankton were isotopically lighter, i.e. $-17.1,-17.3$ and $-15.8 \%$ for $20: 4(n-6), 20: 5(n-3)$ and 22:6(n-3) respectively (Table 2 ).

The NMIDs 20:2 $\Delta 5,13$ and 22:2 27,15 were detected in both Rimicaris exoculata and Alvinocaris markensis, although they were only relatively minor components of their fatty acid pools (Fig. 1, Table 1). NMIDs were most abundant in $R$. exoculata and when combined, comprised totals of $1.6,2.3,2.5$ and $3.1 \%$ of fatty acids in the abdominal muscle, digestive gland, gills and carapace respectively. In A. markensis these fatty acids were present in lower proportions and did not exceed $0.9 \%$ of total fatty acid (Fig. 1, Table 1 ).

The PUFA 20:5(n-3) and 22:6(n-3) were particularly abundant in Alvinocaris markensis (Fig. 1, Table 1). The abdominal and digestive gland of $A$. markensis both contained similar proportions of $22: 6(n-3)$, i.e. 17.1 and $18.1 \%$, whilst the abdominal muscle contained approximately twice the levels of 20:5(n-3) as the digestive gland (16.2 and $7.9 \%$ respectively). Substantially smaller amounts of these PUFA were present in Rimicaris exoculata, particularly the digestive gland, carapace and gills, where they each comprised only 2.9 to $6.1 \%$ of total fatty acids. However, abdominal

Table 2. Rimicaris exoculata. Carbon stable isotope measurements of various tissues from the TAG vent site

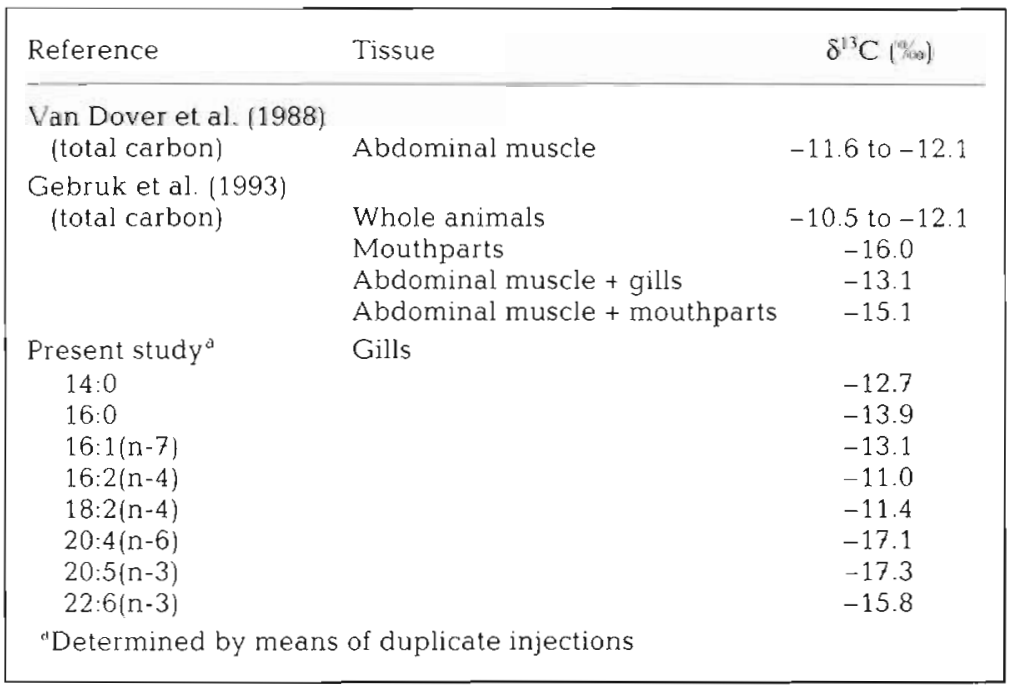

muscle contained relatively high amounts of 20:5(n-3) and $22: 6(n-3)(9.7 \%$ and $11.4 \%$ respectively).

\section{DISCUSSION}

\section{Trophic ecology}

The striking differences between the fatty acid compositions of Rimicaris exoculata and Alvinocaris markensis support published observations on the trophic ecology of these 2 species, which suggested that they occupy different ecological niches in the vicinity of hydrothermal vents (Segonzac et al. 1993). $R$. exoculata tends to swarm around the venting chimneys and is thought to derive nutrition both from bacterial production associated with the surface of the vent mounds and the ectosymbiotic filamentous bacteria which proliferate on the animal's hard surfaces, particularly within the enlarged gill chambers which are characteristic of this species (Van Dover et al. 1988, Gebruk et al. 1993). The relatively low proportions of (n-3) PUFA coupled with the high levels of monounsaturated fatty acids and the low $18: 1(n-9) / 18: 1(n-7)$ ratio confirms that bacteria are a major source of nutrition for $R$. exoculata. By contrast, it has been proposed by Segonzac et al. (1993) that $A$. markensis adopts a more necrophagous, scavenging mode of feeding (which is borne out by the the more typical shrimp-like feeding appendages and the more massive chelae). A higher ratio of $18: 1(n-9) / 18: 1(n-7)$ and the substantial levels of (n-3) PUFA indicates that the diet of $A$. markensis is relatively rich in such compounds and this is consistent with a necrophagous lifestyle in which feeding on animal tissue may predominate, but the possibility of a phytodetrital contribution in its diet cannot be excluded. The larvae of vent shrimp are also known to adopt a typically bathypelagic lifestyle (Dixon \& Dixon 1996, Herring 1996, Pond et al. 1997) and also contain high levels of $(n-3)$ PUFA. As these larvae travel considerable distances from the vent sites, they presumably must rely on phytodetritus for a least at portion of their dietary requirements (Pond et al. 1997).

\section{Dienoic fatty acid synthesis}

A notable finding in the present investigation was the high abundances of $16: 2 \Delta 9,12$ and $18: 2 \Delta 11,14$ fatty acids in the lipids of Rimicaris exoculata where 
they comprised up to $38.3 \%$ of total fatty acid. $16: 2(n-4)$ is readily synthesised by some species of marine photosynthetic algae which possess active $\Delta 9$ and $\Delta 12$ fatty acid desaturases. Diatoms generally contain 16:2(n-4) (Chuecas \& Riley 1969, Volkman et al. 1989), although its fatty acids are not elongated further to $18: 2(n-4)$ in these algae, or in animals that ingest it. Material from the euphotic zone can sediment rapidly to the deep ocean (Lampitt 1985) and scanning electron microscopy of particulate matter from the neutrally buoyant plumes of hydrothermal vents, including TAG, has indicated the presence of biological material originating in the euphotic zone (Dixon et al. 1995). However, in the typically oligotrophic mid-Atlantic waters in the vicinity of the TAG and Snake Pit vent sites, it is unlikely that substantial amounts of phytodetritus are sedimenting to the ocean floor, and it is more probable that the (n-4) fatty acids are synthesised by organisms within the vent ecosystem.

We suggest that the 16:2(n-4) detected here is synthesised by a $\Delta 12$ desaturase acting on $16: 1(n-7)$, a fatty acid which is generally abundant in bacteria. Until relatively recently it was considered that bacteria are incapable of synthesising PUFA as they lack the necessary fatty acid desaturases. However, it is now firmly established that some deep-sea bacteria can be prolific producers of 20:5(n-3) and 22:6(n-3) PUFA (De Long \& Yayanos 1986), as can some bacterial strains isolated from fish intestines (Yazawa et al. 1988). We found the highest levels of (n-4) dienoic fatty acids, both $16: 2(n-4)$ and $18: 2(n-4)$, in the digestive gland of Rimicaris exoculata and this could be associated with the abundances of bacteria in this organ which serves, amongst other things, a digestive function. Van Dover et al. (1988) noted high bacterial densities in the gut of $R$. exoculata $\left(10^{9}\right.$ cells $\left.\mathrm{ml}^{-1}\right)$ although they did not observe any morphological characteristics of the digestive system which suggested the presence of endosymbiotic bacteria. However, $R$. exoculata appears to ingest substantial amounts of metallic sulphide crystals which could potentially be utilised by gut bacteria as an energy source. It is possible that these gut bacteria could contribute to the animal's diet, not in a bulk energy sense, but by the provision of essential dietary components. Jacq et al. (1989) detected small amounts C18 and C20 PUFA in a strain of filamentous bacteria (Thiothrix sp.) sampled from a coastal hydrothermal vent, which is similar to the bacteria found at deep-sea vents. It is also significant that Thiothrix sp. can be a nutritious food source and supports high growth rates in subtidal gastropods at coastal hydrothermal vents (Stein 1984).

$\Delta 12$ desaturases have not previously been detected in marine animals, and it is therefore very unlikely that the vent shrimp itself forms $16: 2(n-4)$. It is notable that photosynthetic prokaryotes, e.g. Synechococcus sp., readily produce $18: 2(n-6)$ as they contain a $\Delta 12$ desaturase (Goodloe \& Light 1982). However, as far as we know, a $\Delta 12$ desaturase has not been found in a chemoautotrophic prokaryote. The supposition that $16: 2(n-4)$ and $18: 2(n-4)$ are derived from bacteria is supported by the stable isotope analyses of the 16:2(n4) and 18:2(n-4) fatty acids in Rimicaris exoculata. Previous carbon stable isotope measurements of total carbon from $R$. exoculata vary from -10.5 to $-16.0 \%$ which suggests that the majority of carbon in this shrimp is of chemosynthetic origin (Van Dover et al. 1988, Gebruk et al. 1993; Table 2). As bulk carbon isotopic compositions of phytoplanktonic material from the shallow ocean are typically in the range -17 to $-28 \%$ (Goericke et al. 1994) and given that the (n-4) dienoic acids here had isotopic values of -11.0 to $-11.4 \%$, this supports the notion that these fatty acids are synthesised within the vent ecosystem and that they are of bacterial origin. By contrast, 20:4(n-6), $20: 5(n-3)$ and $22: 6(n-3)$ were comparatively isotopically light $(-17.1,-17.3$ and $-15.8 \%$ respectively) which is consistent with a photic origin for these fatty acids.

If it is indeed true that $16: 2(n-4)$ is of bacterial origin, what then is its functional/physiological significance? De Long \& Yayanos $(1985,1986)$ have established that the fatty acid composition of deep-sea bacteria responded to increasing pressure by synthesising greater amounts of unsaturated fatty acids in order to optimise membrane fluidity and function. It is therefore plausible that the bacteria associated with the Snake Pit and TAG hydrothermal vent sites synthesise $16: 2(n-4)$ as an adaptation to the temperature extremes and high hydrostatic pressures which are a characteristic of this bathypelagic environment

Converting $16: 2(n-4)$ to $18: 2(n-4)$ requires an elongase which is an abundant enzyme in all marine organisms. It is therefore plausible that Rimicaris exoculata, having derived 16:2(n-4) from its diet, then elongates it to $18: 2(n-4)$. It is well established that C16 PUFA are generally very minor components of animal cell membranes, possibly because they are of insufficient length for correct membrane functioning. Alvinocaris markensis also contains these fatty acids but in much lower levels, and as this species is not directly a bacterial feeder, it is consistent with the ( $n-4)$ fatty acids being originally of bacterial origin. The low levels of ( $\mathrm{n}-4)$ fatty acids in $A$. markensis probably originate from necrophagy on other vent organisms essentially lacking these fatty acids and suggest that dead $R$. exoculata are not a major component of its diet. However, the possibility that these fatty acids are efficiently catabolised by $A$. markensis cannot be excluded. 
The NMIDs $20: 2 \Delta 5,13$ and $22: 2 \Delta 7,15$ detected in the vent shrimp are thought to be derived from bacterial $18: 1(n-7)$ by chain elongation to $20: 1(n-7)$ and desaturation by a $\Delta 5$ desaturase to produce $20: 2 \Delta 5,13$, followed by further chain elongation to $22: 2 \Delta 7,15$ (Ackman \& Hooper 1973, Zhukova 1991, Fullarton et al. 1995). Animals which synthesise NMIDs typically have diets which are rich in 16:0, 16:1(n-7) and 18:1(n-7) with a relative deficiency of PUFA, i.e. typically bacterial. We detected higher proportions of NMIDs in Rimicaris exoculata than Alvinocaris markensis which is consistent with $R$. exoculata deriving a greater proportion of its diet from bacterial sources. However, even in $R$. exoculata the amounts of these NMIDs did not exceed 1 to $2 \%$ of total fatty acids, which is considerably lower than the value of 15 to $20 \%$ reported for the littoral symbiotic bivalve Lucinoma borealis (Fullarton et al. 1995) and 12.2 to $17.7 \%$ for the hydrocarbon seep mussel (Fang et al. $1993 b)$. It is probable that a high dietary input of ( $n-4)$ PUFA precludes the necessity of $R$. exoculata to synthesise NMIDs from 18:1(n-7).

It is possible that the differences in fatty acid composition between the 2 species could result from the different vent sites from which the animals were collected, i.e. Rimicaris exoculata was from the TAG and Alvinocaris markensis from the Snake Pit site. However, the $R$. exoculata from the Snake Pit site, although only a single specimen, did contain high levels of $(n-4)$ fatty acids which suggests that the observed differences between the 2 shrimp species result from their trophic ecology rather than differences in nutritional environment.

In summary, fatty acids analyses of adult Rimicaris exoculata and Alvinocaris markensis have clearly indicated that these species occupy different ecological niches in the MAR vent environment, which confirms the observations of Segonzac et al. (1993). There is strong evidence to suggest that the filamentous chemoautotrophic bacteria associated with the vent ecosystem contain a $\Delta 12$ desaturase. This supposition, if correct, may have considerable implications for our understanding of the nutrition of vent communities in particular and deep sea organisms in general.

Acknowledgements. This work was funded by a Natural Environment Research Council (NERC) PRIME research grant to D.W.P. (grant GST/02/1075), and by research grants to D.R.D. from the NERC (BRIDGE: GST/02/143) and the European Union (MAST3, AMORES: PL950040). We are grateful to Catherine Mevel (chief scientist on the Hydrosnake cruise), Prof. Paul Tyler (University of Southampton) and Dr Michel Segonzac (IFREMER, Brest) for supplying the specimens used in this study. The animal identifications were confirmed by $D$ r Michele de Saint Laurent (Museum of Paris). We also thank J. Dick for assistance with GC-MS of the fatty acids and C. Taylor for GC-IRMS. This is PRIME contribution number 47.

\section{LITERATURE CITED}

Abrajano TA Jr, Murphy DE, Fang J, Comet P, Brooks JM $(1994){ }^{13} \mathrm{C} /{ }^{12} \mathrm{C}$ ratios of individual fatty acids of marine mytilids with and without bacterial symbionts. Org Geochem 21:611-617

Ackman RG, Hooper SN (1973) Non-methylene interrupted fatty acids in lipids of shallow-water marine invertebrates: a comparison of two molluscs (Littorina littorea and Lunatia triseriata) with the sand shrimp (Crangon septemspinous). Comp Biochem Physiol B 46:153-165

Casanova B, Brunet M. Segonzac M (1993) L'impact d'une epibiose bacterienne sur la morphologie fonctinnelle de crevettes associeés a l'hydrothermalisme médio-atlantique. Cah Biol Mar 34:573-588

Christie WW (1982) Lipid analyses, 2nd edn. Pergamon Press, Oxford

Chuecas L, Riley JP (1969) Component fatty acids of the total lipids of some marine phytoplankton. J Mar Biol Assoc UK 49:97-116

De Long EF, Yayanos AA (1985) Adaptation of the membrane lipids of a deep-sea bacterium changes to hydrostatic pressure. Science 228:1101-1102

De Long EF, Yayanos AA (1986) Biochemical function and ecological significance of novel bacterial lipids in deepsea procaryotes. Appl Environ Microbiol 51:730-737

Dixon DR, Dixon LRJ (1996) Results of DNA analyses conducted on vent-shrimp postlarvae collected above the Broken Spur vent field during CD95 cruise, August 1995. BRIDGE Newsl 11:9-15

Dixon DR, Jollivet DASB, Dixon LRJ, Nott JA, Holland PWH (1995) The molecular identification of early life-history stages of hydrothermal vent organisms. In: Parson LM, Walker CL, Dixon DR (eds) Hydrothermal vents and processes. The Geological Society, London, p 343-350

Eakin PA, Fallick AE, Gerc J (1992) Some instrumental effects in the determination of stable carbon isotope ratios by gas chromatography-isotope ratio mass spectrometry. Chem Geol 101:71-79

Fang J, Abrajano TA, Comet P, Brooks JM, McDonald I (1993a) Gulf of Mexico hydrocarbon seep communities: XI-carbon isotope fractionation during fatty acid biosynthesis of seep organisms and its implications for chemosynthetic processes. Chem Geol 109:271-279

Fang J, Comet PA, Brooks JM, Wade TL (1993b) Nonmethylene-interrupted fatty acids of hydrocarbon seep mussels: occurrence and significance. Comp Biochem Physiol B 104:287-291

Folch J. Lees N, Sloan-Stanley GH (1957) A simple method for the isolation and purification of total lipid. J Biol Chem 226:497-509

Fullarton JG, Dando PR, Sargent JR, Southward AJ, Southward EC (1995) Fatty acids of hydrothermal vent Ridgeia piscesae and inshore bivalves containing symbiotic bacteria. J Mar Biol Assoc UK 75:455-468

Gebruk AV, Pimenov NV, Savvichev AS (1993) Feeding specialisation of bresiliid shrimps in the TAG site hydrothermal community. Mar Ecol Prog Ser 98:247-253

Goericke R, Montoya JP. Fry B (1994) Physiology of isotopic fractionation in algae and cyanobacteria. In: Lajtha $\mathrm{K}$, Michener RH (eds) Stable isotopes in marine ecology and environmental science. Blackwell Scientific Publications, Oxford, p 187-221

Goodloe RS, Light RJ (1982) Structure and composition of hydrocarbons and fatty acids from a marine blue-green alga, Synechococcus sp. Biochim Biophys Acta 7 10:485-492

Hayes JM (1993) Factors controlling the ${ }^{13} \mathrm{C}$ contents of sedi- 
mentary organic compounds: principles and evidence. Mar Geol 113:111-125

Henderson RJ, BeII MV, Park MT, Sargent JR, Falcon J (1994) Lipid composition of the pineal from rainbow trout (Oncorhynchus mykiss). Lipids 29:311-317

Herring PJ (1996) Travell.ng shrump. BRIDGE News 11:6-8

Jacq E, Prieur D, Nichols P, White DC, Porter T, Geesey GG (1989) Microscopic examination and fatty acid characterization of filamentous bacteria colonizing substrata around subtidal hydrothermal vents. Arch Microbiol 152:64-71

Lampitt RS (1985) Evidence for the seasonal deposition of detritus to the deep-sea floor and its subsequent resuspension. Deep Sea Res 32:885-897

Nilsson R. Liljenberg C (1991) The determination of double bond positions in polyunsaturated fatty acids - gas chromatography/mass spectrometry of the diethylamide derivative. Phytochem Analysis 2:253-259

Pond DW, Dixon DR, Sargent JR (1997) Wax-ester reserves facilitate dispersal of hydrothermal vent shrimps. Mar Ecol Prog Ser 146:289-290

Pranal V, Fiala-Médioni A, Guezennec J (1996) Fatty acid characteristics in two symbiotic gastropods from a deep hydrothermal vent of the West Pacific. Mar Ecol Prog Ser 142:175-184

Rieley G, Van Dover CL, Hedrick DB, White DC, Eglinton G (1995) Lipid characteristics of hydrothermal vent organisms from $9^{\circ} \mathrm{N}$ East Pacific Rise. In: Parson LM, Walker CL, Dixon DR (eds) Hydrothermal vents and processes. The Geological Society, London, p 329-342

Rona PA (1986) TAG hydrothermal field: Mid-Atlantic Ridge crest at latitude $26^{\circ} \mathrm{N}$. J Geol Soc Lond 137:385-402

Sargent JR, Parkes RJ, Mueller-Harvey I, Henderson RJ (1987) Lipid biomarkers in marine ecology. In: Sleigh MA (ed) Microbes in the sea. Ellis Horwood, Chichester, p 119-138

Segonzac M (1992) Les peuplements associés à l'hydrothermalisme océanique du Snake Pit (dorsal médio-atlantique;

This article was submitted to the editor $\left.23^{\circ} \mathrm{N}, 3840 \mathrm{~m}\right)$ : composition et microdistribution de la mégafaune. CR Acad Scu Paris 314:593-600

Segonzac M, Saint Laurent Mde, Casanova B (1993) L'énigme du comportement trophique des crevettes Alvinocarididae des sites hydrothermaux de la dorsale médio-atlantique. Cah Biol Mar 34:535-571

Sofer Z (1980) Preparation of carbon dioxide for stable isotope analysis of petroleum fractions. Anal Chem 52: $1389-1391$

Stein JL (1984) Subtidal gastropods consume sulfur-oxidizing bacteria: evidence from coastal hydrothermal vents. Science 223:696-698

St. John MA, Lund T (1996) Lipid biomarkers: linking the utilization of frontal plankton biomass to enhanced condition of juvenile North Sea cod. Mar Ecol Prog Ser 131:75-85

Van Dover CL (1995) Ecology of Mid-Atlantic Ridge hydrothermal vents. In: Parson LM, Walker CL, Dixon DR (eds) Hydrothermal vents and processes. The Geological Society, London, p 257-294

Van Dover CL, Fry B, Grassle JF, Humphris S, Rona PA (1988) Feeding biology of the shrimp Rimicaris exoculata at hydrothermal vents on the Mid-Atlantic Ridge. Mar Biol $98: 209-216$

Volkman JK, Jeffrey SW, Nichols PD, Rogers GI, Garland CD (1989) Fatty acid and lipid composition of 10 species of microalgae used in mariculture. J Exp Mar Biol Ecol 128 : $219-240$

Wilson R, Sargent JR (1992) High-resolution separation of polyunsaturated fatty acids by argentation thin-layer chromatography. J Chromatogr 623:403-407

Yazawa K, Araki K, Watanabe $K$, Ishikawa $C$, Inoue $A$, Kondo K, Watabe S, Hashimota K (1988) Eicosapentaenoic acid productivity of the bacteria isolated from fish intestines. Nipp Suis Gakk 54:1835-1838

Zhukova NV (1991) The pathway of the biosynthesis of nonmethylene-interrupted dienoic fatty acids in molluscs. Comp Biochem Physiol B 100:801-804

Manuscript received: March 12, 1997

Revised version accepted: July 9, 1997 